$\sqrt{B}$

J. Bio-Sci. 25: 77-81, 2017

ISSN 1023-8654

http://www.banglajol.info/index.php/JBS/index

-Short communication

\title{
ANTIFEEDANT EFFECT OF WATER-SOLUBLE ANTHRAQUINONE PIGMENT OF KERRIA LACCA
}

\author{
G Shamim ${ }^{1,2 *}$, DM Pandey ${ }^{3}$, KK Sharma ${ }^{1}$ and R Ramani ${ }^{1}$ \\ IIndian Institute of Natural Resins and Gums, Namkum, Ranchi, India \\ ${ }^{2} B$ S Abdur Rahman Crescent Institute of Science and Technology, Chennai, India \\ ${ }^{3}$ Birla Institute of Technology, Mesra, Ranchi, India
}

Many hemipteran insects are phytosuccivorous in nature and predominantly feed on phloem sap, xylem sap or mesophyll cell (Novotny and Wilson 1997, Douglas 2006). Indian lac insects, Kerria lacca (Kerr) (Hemiptera: Coccoidea: Tachardiidae (=Kerriidae)) feed on sugar-rich phloem sap (Ahmad et al. 2012) - a chief source of carbon and nitrogen - and excrete excess sugar in the form of honey dew from anal tuberacle which becomes a major cause of fungal contamination. Sugar-rich honey dew attracts ants to feed upon them and thus, this ant-hemipteran mutualistic interaction prevents losses by fungus infection (Sharma and Jaiswal 2011). According to Lu et al. (2012), the presence of lac plantation with lac hosting affects the diversity and abundance of ground dwelling ant species. Among the various ant species which attend lac insects, most are harmless to lac culture, this may be due to the feeding deterrence exhibited by the anthraquinoine pigments found as body colouration of these insects. Wild type insect are crimson in colour due to the presence of a complex of closely resembling water-soluble polyhydroxy-anthraquinones (laccaic acid A, B, C, D and E), collectively called as lac dye. Yellow mutants possess only the precursor molecule laccaic acid D (Shamim et al. 2016a). Apart from these, certain alcohol-soluble anthraquinones such as desoxyerythrolaccin, erythrolaccin and isoerythrolaccin are also found in the resinous secretion of lac insects, giving it yellowish colouration (Fig. 1).

Available literature suggests that carminic acid, an anthraquinone compound obtained from body pigments of a scale insect Dactylopius confusus exhibit antifeedant activity against ants along with various other biological and pharmacological activities and is said to be evolved as a chemical weapon against predation (Eisner et al. 1980). Based on the structural similarities between the anthraquinone present in carminic acid and anthraquinones present in laccaic acids (produced by Kerria lacca); it was assumed that lac dye may also exhibit similar effect. This study aimed for assessment of antifeedant activity of the constituents of lac dye i.e. water-soluble polyhydroxy anthraquinones against ants.

*Author for correspondence: gulsazshamim@gmail.com 
<smiles>CCOCCc1ccc(O)c(-c2c(O)c(O)c3c(c2O)C(=O)c2c(cc(O)c(C(=O)O)c2C(=O)O)C3=O)c1</smiles>

a) Laccaic acid $A$<smiles>Cc1c(C(=O)O)c(O)cc2c1C(=O)c1c(O)cc(O)c(O)c1C2=O</smiles>

d) Laccaic acid D<smiles>Cc1cc(O)c(O)c2c1C(=O)c1c(O)cc(O)c(O)c1C2=O</smiles>

g) Erythrolaccin<smiles>O=C(O)c1c(O)cc2c(c1C(=O)O)C(=O)c1c(O)c(-c3cc(CO)ccc3O)c(O)c(O)c1C2=O</smiles>

b) Laccaic acid B<smiles>NCCc1ccc(O)c(-c2c(O)c(O)c3c(c2O)C(=O)c2c(cc(O)c(C(=O)O)c2C(=O)O)C3=O)c1</smiles>

e) Laccaic acid E<smiles>Cc1cc(O)cc2c1C(=O)c1c(O)cc(O)cc1C2=O</smiles>

h) Desox yerythrolac cin<smiles>CCCCNC(=O)O</smiles>

c) Lacc aic acid C<smiles>COCCc1ccc(O)c(-c2c(O)c(O)c3c(c2O)C(=O)c2c(cc(O)c(C(=O)O)c2C(=O)O)C3=O)c1</smiles><smiles>Cc1cc(O)cc2c1C(=O)c1c(cc(O)c(O)c1O)C2=O</smiles>

i) Isoerythrolac cin

HO

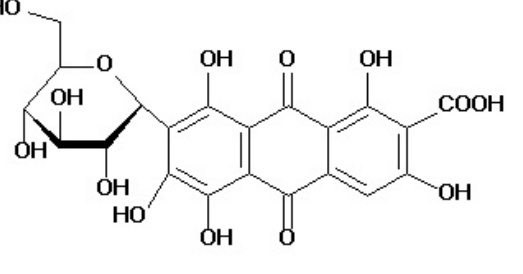

j) Carminic acid

Fig. 1. Chemical structures of polyhydroxy anthraquinone pigments; a - f: Laccaic acids present in lac dye; $g$ - i: laccaic acids found in lac resin; j: Carminic acid produced by D. confuses (Shamim et al. 2016a).

For the assessment of antifeedant activity of the anthraquinones found in lac pigments, crimson and yellow insect cell extracts were used along with pure crimson dye, which served as a negative control. This work was carried out at Indian Institute of Natural Resins and Gums (IINRG), Namkum, Ranchi, India and both wild type crimson insects and yellow mutants were obtained from the Field Gene Bank at National Lac Insect Germplasm Centre (NATLIGEC) of the same institution. Also, the crude crimson lac dye was obtained from IINRG's pilot plant facility for lac dye extraction. To purify crude dye, it was dissolved in water and filtered repeatedly using filter paper of $0.19 \mathrm{~mm}$ thickness (sartorius stedium biotech, 292a) and air dried at $40^{\circ} \mathrm{C}$ for 24-48 hrs. Pure dye thus obtained was checked for complete solubility in deionized water. Crude pigment extract of both wild type crimson and mutant yellow insect was prepared simply by grinding the insects in sterile water. 
Deterrence of anthraquinones was assessed by offering sugar solutions laced with insect extracts to predaceous ants (Eisner and Meinwald 1965, Carrel and Eisner 1974, Montllor et al. 1991, Hare and Eisner 1993, Schaffner et al. 1994, Morton and Vencl 1998, Gomez et al. 1999, Vencl et al. 1999). Eighty percent sucrose solution was used as a positive control in this study. Sterilized sponges $(3.5 \times 1 \mathrm{~cm})$ were soaked with the dye and cell extracts respectively, and then covered with the sucrose solution. One set of pure lac dye and insect extract samples were kept without lacing it with sugar solution. These sponges were kept on sterile slides and were placed near ant hill to assess the antifeedant activity of the anthraquinones under natural conditions where lac insects are being cultured on Flemingia semialata plants and are being antattended on regular basis. For the similar study under laboratory conditions, the ants were collected from the field where lac insects are cultivated; these ants were left for feeding on the samples under a glass chamber with proper aeration. Feeding behaviour of ants towards the lac dye was observed for an hour and number of ants feeding on it was recorded.

This behavioural study to investigate deterrence of lac dye components led to the observation that yellow dye containing laccaic acid D was most susceptible to ants attack as observed by the maximum number of ants feeding on the sucrose sample overlaid on the cell extract of yellow insects. At the outset of the experiment, it was noted that ants were attracted towards the positive control of experimental set up. They started feeding on the positive control containing only sugar solution but in the test samples i.e. the lac dye coated with sucrose solution, ants visited the periphery and left without feeding. Gradually, the deterrence of the test samples decreased and ants also attended the test samples along with the positive control. No significant result was observed in the negative controls where no sugar solution was added. Pure crimson dye along with sucrose was more attended by ants as compared to the crimson cell extract. At both the assay conditions similar observations were recorded and no significant differences were found (Fig. 2).

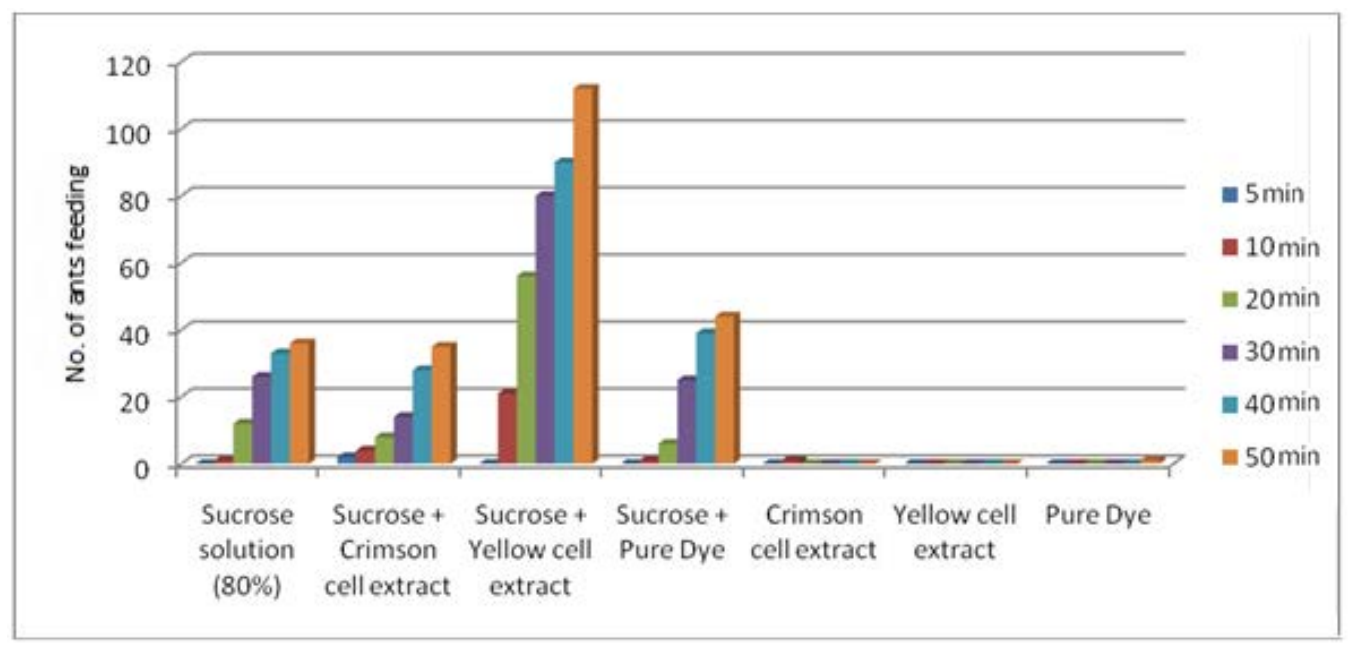

Fig. 2. Graph depicting the observation of the antifeedant assay; yellow cell extract is least deterrent to ants whereas crimson cell extract shows maximum deterrence.

Anthraquinone pigments in insects have been observed to play wide variety of important roles. Apart from being associated with immunity, life-history, physiological, and developmental traits, these pigment molecules exhibit antimicrobial (Cudlin et al. 1976, Manojlovic et al. 2000, Izhaki 2002, Kambizi et al. 2004) and antiviral activity (Barnard et al. 1992, Semple et al. 2001) and protects insects from microbial attack and 
viral infections, respectively. For example, carminic acid is reported to show cytostatical activity (Gálvez et al. 1996). Lac dye has also been reported to show antineoplastic effect against leukemia cell lines (Shamim et al. 2016b). Feeding deterrence by anthraquinones is also well reported; anthraquinone synthesised by Dactylopius confusus is deterrent against ants (Eisner et al. 1980). Apart from these, several anthraquinones and anthrones showing antifeedant activity against avian predators (Schafer et al. 1983, Hilker and Köpf, 1995, Avery et al. 1997) have found their application in wildlife management, where seeds are treated with anthraquinones against avian pests (Avery et al. 1997).

In this study dealing with antifeedant effect of water-soluble anthraquinone pigment, it was observed that yellow dye containing laccaic acid D was most susceptible to ants attack whereas, a mixture of laccaic acids in crimson dye is more effective in exhibiting feeding deterrence on ants. The pure crimson dye is less effective than the cell extract of crimson coloured insects, it could be due to the loss of deterrence during the processing and purification of the dye or feeding deterrence could be due to a cumulative effect of a mixture of compounds along with the pigment molecule. There is still a gap in the understanding of antifeedant effect of anthraquinones and therefore, it is suggested that $K$. lacca anthraquinones should be explored more as potential natural antifeedant, based on its active constituents.

\section{Acknowledgement}

This study has been supported by funds from National Agriculture Innovation Project. We would like to thank Mr. Parvez Ansari, Mr. B. Oraon and Mr. Bhupal Kumar for their technical assistance.

\section{References}

Ahmad A, Kaushik S, Ramamurthy VV, Lakhanpaul S, Ramani R, Sharma KK and Vidyarthi AS (2012). Mouthparts and stylet penetration of the lac insect Kerria lacca (Kerr) (Hemiptera:Tachardiidae), Arthropod Structure and Development 41(5): 435-441.

Avery ML, Humphrey JS and Decker DG (1997). Feeding deterrence of anthraquinone, anthracene, and anthrone to riceeating birds, The Journal of Wildlife Management 61: 1359-1365.

Barnard DL, Huffman JH, Morris JLB, Wood SG, Hughes BG and Sidwell RW (1992). Evaluation of the antiviral activity of anthraquinones, anthrones and anthraquinone derivates against human cytomegalovirus, Antiviral Research 17: 63-77.

Carrel JE and Eisner T (1974). Cantharidin: Potent Feeding Deterrent to Insects, Science 183: 755-757.

Cudlin J, Blumauerova M, Steinerova N, Mateju J and Zalabak V (1976). Biological activity of hydroxyanthraquinones and their glucosides towards microorganisms, Folia Microbiologica 21: 54-57.

Douglas AE (2006). Phloem-sap feeding by animals: problems and solutions, Journal of Experimental Botany 57(4): 747754.

Eisner T and Meinwald YC (1965). Defensive secretion of a caterpillar (Papilio), Science 150: 1733-1735.

Eisner T, Nowicki S, Goetz M and Meinwald J (1980). Red cochineal dye (carminic acid): Its role in nature, Science 208 : 1039-1042.

Gálvez J, Gomez-Lechón MJ, García-Domenech R and Castell JV (1996). New cytostatic agents obtained by molecular topology, ¡Bioorganic and Medicinal Chemistry Letters 6: 2301-2306.

Gomez NE, Witte L and Hartmann T (1999). Chemical defense in larval tortoise beetles: Essential oil composition of fecal shields of Eurypedus nigrosignata and foliage of its host plant, Cordia curassavica, Journal of Chemical Ecology 25: 1007-1027. 
Hare JF and Eisner T (1993). Pyrrolizidine alkaloid deters ant predators of Utetheisa ornatrix eggs - effects of alkaloid concentration, oxidationstate, and prior exposure of ants to alkaloid-laden prey, Oecologia 96: 9-18.

Hilker M and Köpf A (1995). Evaluation of the palatability of chrysomelid larvae containing anthraquinones to birds, Oecologia 100: 421-429.

Izhaki I (2002). Emodin - a secondary metabolite with multiple ecological functions in higher plants, New Phytologist 155 : 205-217.

Kambizi L, Sultana N and Afolayan AJ (2004). Bioactive compounds isolated from Aloe ferox: A plant traditionally used for the treatment of sexually transmitted infections in the Eastern Cape, South Africa, Pharmaceutical Biology 42: 636-639.

Lu ZX, Chen YQ, Li Q, Wang SM, Liu CJ and Zhang W (2012). Effects of lac insect honeydew on the diversity of grounddwelling ants in lac plantation, Yingyong Shengtai Xuebao 23 (4): 1117-1122.

Manojlovic NT, Solujic S, Sukdolak S and Krstic LJ (2000). Isolation and antimicrobial activity of anthraquinones from some species of the lichen genus Xanthoria, Journal of the Serbian Chemical Society 65: 555-560.

Montllor CB, Bernays EA and Cornelius ML (1991). Responses of 2 hymenopteran predators to surface-chemistry of their prey - significance for an alkaloid-sequestering caterpillar, Journal of Chemical Ecology 17: 391-399

Novotny V and Wilson MR (1997). Why are there no small species among xylem sucking insects, Evolutionary Ecology 11:419-437

Morton TC and Vencl FV (1998). Larval beetles form a defense from recycled host-plant chemicals discharged as fecal wastes, Journal of Chemical Ecology 24: 765-785.

Schafer EW, Bowles WA and Hurlbut J (1983). The acute oral toxicity, repellency, and hazard potential of 998 chemicals to one or more species of wild and domestic birds, Archives of Environmental Contamination and Toxicology 12: 355-382.

Schaffner U, Boeve JL, Gfeller H and Schlunegger UP (1994). Sequestration of veratrum alkaloids by specialist Rhadinoceraea nodicornis Konow (Hymenoptera, Tenthredinidae) and its ecoethological implications, Journal of Chemical Ecology 20: 3233-3250.

Semple SJ, Pyke SM, Reynolds GD and Flower RLP (2001). In vitro antiviral activity of the anthraquinone chrysophanic acid against poliovirus, Antiviral Research 49: 169-178.

Shamim G, Pandey DM, Sharma KK and Ramani R (2016a). Genes involved in the biosynthesis of lac dye constituents in Indian Lac Insect, Kerria lacca (Kerr), Journal of the Entomological Research Society 18 (1): 7-17.

Shamim G, Ranjan SK, Pandey DM, Sharma KK and Ramani R (2016b). Lac dye as a potential anti-neoplastic agent, ¡Journal of Cancer Research and Therapeutics 12 (2): 1033-1035.

Sharma KK and Jaiswal A K. (2011). Genetic variability in lac insects. In: Kumar KK, Ramani R and Sharma KK (Eds.). Recent advances in lac culture. ILRI, Ranchi, India, 112-115 pp.

Vencl FV, Morton TC, Mumma RO and Schultz JC (1999). Shield defense of a larval tortoise beetle, Journal of Chemical Ecology 25: 549-566. 
